\title{
A novel filamentous phage, fs-2, of Vibrio cholerae 0139
}

\author{
Masahide Ikema and Yasuko Honma
}

Department of

Bacteriology, Faculty of Medicine, University of the Ryukyus, 207 Nishihara Okinawa 903-0215, Japan

\author{
Author for correspondence: Masahide Ikema. Tel: +8198 895 3331. Fax: +8198 8952951 \\ e-mail: k960416@eve.u-ryukyu.ac.jp
}

\begin{abstract}
A novel filamentous bacteriophage, fs-2, was isolated from Vibrio cholerae 0139 strain MD014. The fs-2 phage was a long filamentous particle $1200 \mathrm{~nm}$ long and $7 \mathrm{~nm}$ wide. The purified phage formed a turbid plaque when spotted on a lawn of the host organisms. The plaque-formation activity was stable following heating to $70^{\circ} \mathrm{C}$ but was inhibited by treatment with chloroform. fs2 had a single-stranded DNA genome and was converted to a double-stranded replicative form in the host cell. Almost all V. cholerae 0139 and 01 El Tor biotype strains tested were sensitive to the phage, but most 01 classical strains and non-01 non-0139 strains were resistant. The fs-2 genome comprised 8651 nucleotides containing nine open reading frames, five of which had predicted protein products partially homologous to the reported protein products of other filamentous phages. Although the extent of the homology was not particularly high, the genetic organization of other fllamentous phages appears to be preserved in fs-2. The phage was not integrated into the chromosome of its host, but a 715 nucleotide fragment located in the large intergenic region of fs-2 was highly homologous to a part of region RS2 (repetitive sequence 2) of the $V$. cholerae CTXФ sequence which is speculated to be required for integration of the phage into the $V$. cholerae chromosome at a specific site.
\end{abstract}

Keywords: Vibrio cholerae $\mathrm{O} 139$, filamentous phage

\section{INTRODUCTION}

Vibrio cholerae is the host for a variety of phages (Rowe $\&$ Frost, 1992). Some of the well-known groups are represented by kappa-type phage (temperate phage), which is produced by most strains of El Tor biotype, and Mukerjee's cholera phages (virulent phage), which are used for phage typing of $V$. cholerae $\mathrm{O} 1$. Another group is represented by the filamentous phages which have a single-stranded DNA genome. This group has been well studied in Escherichia coli (coliphages) and has been used to develop cloning vectors. Recently, Kar et al. (1996) reported the isolation of filamentous phage VSK from $V$. cholerae O139. VSK is unusual in that it can integrate its genome into the host chromosome and enter the lysogenic state. Another filamentous phage of $V$. cholerae designated CTX $\Phi$ was reported by Waldor \& Mekalanos (1996). They reported that the CTXФ

Abbreviation: RF, replicative form.

The DDBJ accession number for the sequence reported in this paper is AB002632. genome contained the entire virulence cassette (CTX element) including the gene for cholera toxin $(c t x)$, and it can either replicate as a plasmid or integrate into the $V$. cholerae chromosome at a specific site (Waldor et al., 1997). The authors speculated that the phage is involved in horizontal gene transfer of virulence determinants. Although this has not yet been shown to occur in the natural environment, the speculation is an attractive explanation of the emergence of a novel toxigenic $V$. cholerae 0139 in India in 1992 (Rammanurthy et al., 1993). We have found novel filamentous phages fs-1 (Ehara et al., 1997; Shimodori et al., 1997) and fs-2 from V. cholerae O139. In this communication, we describe the general characteristics and genetic analysis of phage fs-2.

\section{METHODS}

Bacterial strains and media. V. cholerae 0139 strain MDO14 was used for phage preparation. $V$. cholerae $\mathrm{O} 1$, serotype Ogawa, biotype El Tor, strain 88UDT109 was used as an indicator strain to detect the phage. When necessary, $V$. cholerae strains from our laboratory collection were also used. 
E. coli XL-1 Blue (Stratagene) was used as the host for molecular cloning. Alkaline tryptone (per litre: $1 \mathrm{~g}$ tryptone, $0.3 \mathrm{~g}$ yeast extract, $0.5 \mathrm{~g} \mathrm{NaCl}, 0.01 \mathrm{~g} \mathrm{NaHCO}_{3}$ ) or heart infusion broth were used for the culture of $V$. cholerae. Luria-Bertani (LB) broth (per litre: $1 \mathrm{~g}$ tryptone, $0.5 \mathrm{~g}$ yeast extract, $0.5 \mathrm{~g} \mathrm{NaCl}$ ) or LB agar plates supplemented with ampicillin $\left(100 \mu \mathrm{g} \mathrm{ml}^{-1}\right)$ were used for growth of E. coli containing cloning vectors.

Purification of fs-2 phage. $V$. cholerae strain MDO14 was cultured in alkaline tryptone at $37^{\circ} \mathrm{C}$ for $18 \mathrm{~h}$ with shaking. The supernatant was filtered through a $0.45 \mu \mathrm{m}$ pore size membrane and salted out with $10 \%$ saturated ammonium sulfate. The precipitate collected by centrifugation $(16000 \mathrm{~g}$, $20 \mathrm{~min}$ ) was suspended in $10 \mathrm{mM}$ phosphate-buffered saline ( $\mathrm{pH} 7 \cdot 4)$ and dialysed against the same buffer. This sample was fractionated by sucrose density-gradient centrifugation (sucrose gradient ranging from 10 to $60 \%$, w/v; $152000 \mathrm{~g}$, $12 \mathrm{~h}$ ). The purity of the phage in the fractions was examined by electron microscopy and electrophoresis.

Isolation of phage genome and replicative-form (RF) DNA. The fs-2 genome was isolated from the purified phage using phenol/chloroform extraction (Sambrook et al., 1989). The RF DNA of fs-2 phage was isolated from V. cholerae O139 strain MDO14 by the method of Birnboim \& Doly (1979). The DNA was electrophoresed on $0.9 \%(w / v)$ agarose gel and visualized with ethidium bromide or acridine orange. Acridine orange interacts differently with double- and single-stranded DNA, fluorescing green and orange, respectively (McMaster \& Carmichael, 1977).

Electron microscopy and electrophoresis. The purified phage was negatively stained with $4 \%(\mathrm{w} / \mathrm{v})$ uranyl acetate and observed in a Hitachi H-7500 transmission electron microscope. Protein analysis was carried out by SDS-PAGE and immunoblotting as described by Laemmli (1970) and Towbin et al. (1979) respectively.

Preparation of antisera. A rabbit (Japanese White, $2 \mathrm{~kg}$ ) was immunized with $0.1 \mathrm{mg}(1 \mathrm{ml})$ purified $\mathrm{fs}-2$ phage every 2 weeks. One millilitre of antigen emulsified with the same volume of Freund's complete adjuvant was injected subcutaneously. For the boosting injection, $0 \cdot 1 \mathrm{mg}$ fs- 2 phage and Freund's incomplete adjuvant was used.

Plaque-formation test and host range. A $0.1 \mathrm{ml}$ sample from an overnight culture of $V$. cholerae strains in heart infusion broth was mixed well with $4 \mathrm{ml}$ soft agar (per litre: $1 \mathrm{~g}$ peptone, $0.5 \mathrm{~g}$ yeast extract, $0.5 \mathrm{~g} \mathrm{NaCl}, 0.6 \mathrm{~g}$ agar) at $45^{\circ} \mathrm{C}$, and overlaid on a glass slide. Five microlitres $\left(10^{9}\right.$ p.f.u. $\left.\mathrm{ml}^{-1}\right)$ of phage solution was spotted on the layer and incubated at $37^{\circ} \mathrm{C}$ overnight. The stability of plaque-formation activity to heat and organic solvents was examined using the method of Taniguchi et al. (1984). To determine the host range of the fs2 phage, the plaque-formation test was performed with $93 \mathrm{~V}$. cholerae $\mathrm{O} 1 \mathrm{El}$ Tor strains, $50 \mathrm{~V}$. cholerae $\mathrm{O} 1$ classical strains, $49 \mathrm{~V}$. cholerae $\mathrm{O} 139$ strains and $34 \mathrm{~V}$. cholerae non-O1, nonO139 strains from our laboratory collection.

Southern hybridization. DNA was electrophoresed on $0.9 \%$ $(w / v)$ agarose gel and transferred to a nylon membrane (Hybond- $\mathrm{N}^{+}$; Amersham). Labelling of the DNA probe with horseradish peroxidase and detection of the signal were carried out by using ECL direct nucleic acid labelling and detection systems (Amersham). The procedures for blotting, hybridization and washing were carried out under highstringency conditions as described in the instruction manual.

Cloning and DNA sequencing. The RF DNA of the fs- 2 phage was digested with EcoRI, DraI, StyI, BssHII, HpaI, SspI,
HindIII, XbaI, Accl and ScaI. Restriction fragments were cloned into the phagemid vector pBluescript II $\mathrm{KS}^{+}$ (Stratagene) and then transformed into E. coli XL-1 Blue. Exonuclease III and mung bean nuclease (Takara Shuzo) were also used to generate the subclones of nested deletions. The cloned plasmid DNA was isolated by the alkaline lysis method using a Qiagen Plasmid kit (Funakoshi). Sequencing was performed by the dideoxynucleotide triphosphate chaintermination method (Sanger et al., 1977) with a Thermo Sequence pre-mix cycle sequencing kit (Amersham) and a Hitachi SQ-5500 sequencer. The program BLAST 1.4.9 (Altschul et al., 1990) was used to search for homologous sequences in the databases.

\section{RESULTS}

\section{Purification, characteristics and host range of fs-2 phage}

The pellet obtained by salting out the culture supernatant with ammonium sulfate contained almost pure phage with only a small amount of cellular contamination. In the further purification procedure using sucrose density-gradient centrifugation, $\mathrm{fs}-2$ was concentrated at a sucrose density of $34-41 \%(\mathrm{w} / \mathrm{v})$.

Electron microscopy revealed the filamentous nature of the fs- 2 phage particles: approximately $7 \mathrm{~nm}$ wide and $1200 \mathrm{~nm}$ long (Fig. 1). The purified fs- 2 phage made a turbid plaque when it was spotted on host strains. The SDS-PAGE profile of proteins prepared from the purified fs- 2 phage revealed a single band of about $4.5 \mathrm{kDa}$ (Fig. $2 \mathrm{a}$, lane 2) which was not cross-reactive with protein from another novel filamentous phage, fs-1 (Ehara et al., 1997; Shimodori et al., 1997), in Western blot analysis (Fig. 2b).

The plaque-formation activity of the phage was stable at temperatures below $70^{\circ} \mathrm{C}$ for $10 \mathrm{~min}$ but was inhibited completely by heating to $80^{\circ} \mathrm{C}$. It was also inhibited by

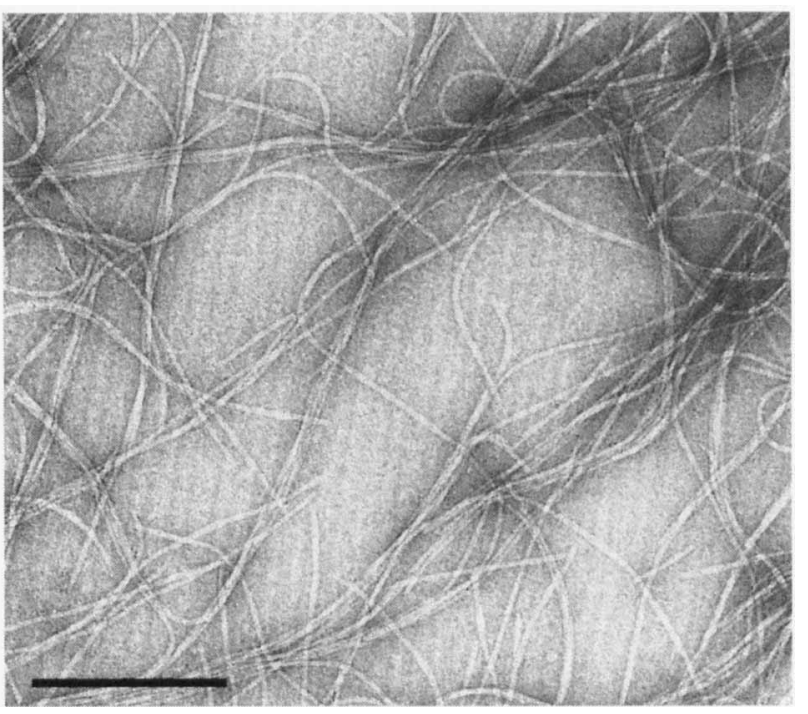

Fig. 1. Electron micrograph of negatively stained purified fs-2 phage. Bar, $300 \mathrm{~nm}$. 


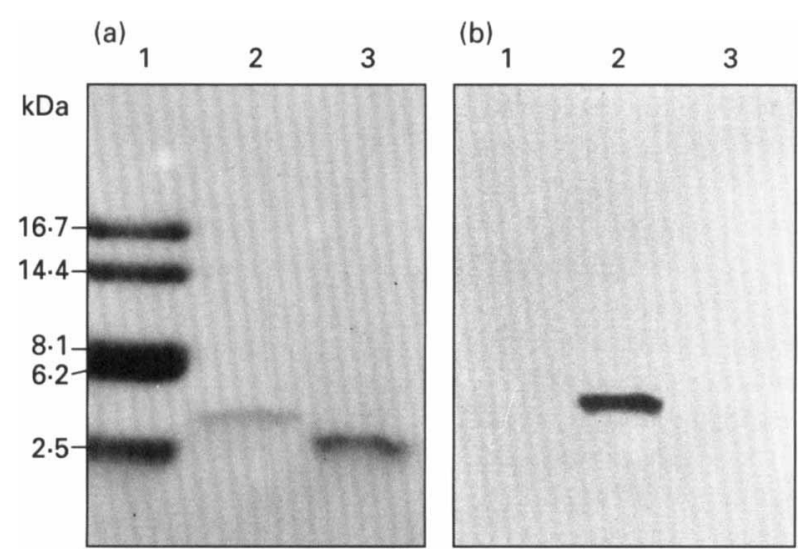

Fig. 2. (a) Coomassie brilliant blue stained SDS-PAGE profile. (b) Western blotting with the anti-fs- 2 phage antiserum (diluted 1:100). Lane 1, molecular mass markers (Pharmacia LKB Biotechnology); lane 2, purified fs-2 phage; lane 3, fs-1, another novel filamentous phage of $V$. cholerae 0139.

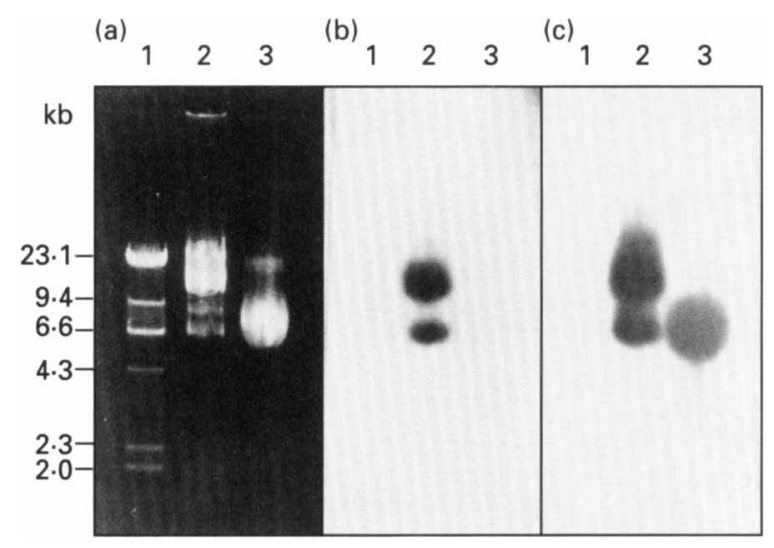

Fig. 3. (a) $0.9 \%$ (w/v) agarose gel electrophoresis. (b) Southern hybridization analysis with single-stranded phage DNA as a probe. (c) Southern hybridization analysis with putative RF DNA obtained from strain MDO14 as a probe. Lane 1, molecular mass markers (HindIII digest of $\lambda$ DNA); lane 2, plasmid obtained from strain MDO14; lane 3, single-stranded phage genome DNA.

treatment with chloroform but resistant to treatment with methanol, acetone and diethyl ether.

The plaque-formation test gave positive results in $89 \%$ (83 of 93) of the O1 El Tor strains, $8 \%$ (4 of 50) of the O1 classical strains, $78 \%$ (38 of 49 ) of the O139 strains and $17 \%$ (6 of 34 ) of the non-O1 non-O139 strains.

\section{fs-2 phage genome}

The DNA purified from the phage migrated to a position corresponding to a size between 9.4 and $6.6 \mathrm{~kb}$ on agarose gel electrophoresis (Fig. 3a, lane 3). The phage genome was resistant to $\mathrm{RNase}$ and all restriction enzymes tested. On the other hand the fs-2-producing strain MDO14 contained a plasmid of $8.5 \mathrm{~kb}$ which was thought to be the RF DNA (Fig. 3a, lane 2). The phage genome was stained orange by acridine orange, indicating single-stranded DNA (McMaster \& Carmichael, 1977), while the plasmid obtained from strain MDO14 stained green, indicating double-stranded DNA. In Southern hybridization analysis using horseradishperoxidase-labelled fs- 2 phage DNA as a probe, the probe hybridized with the plasmid but not with the phage DNA (Fig. 3b). When the plasmid was used as a probe, it hybridized with both plasmid and phage DNA (Fig. 3c). On the basis of these results we concluded that the plasmid found in MDO14 is the RF of the singlestranded phage DNA.

\section{Nucleotide sequence of the fs- 2 genome}

The sequence of the fs- 2 RF was determined on both strands on overlapping DNA fragments, and a homology search was performed for the presumed open reading frames (ORFs) in both strands. ORFs homologous to the genes of other filamentous phages were located on one of the strands. Therefore we postulated that the sequence submitted to DDBJ with the accession number $\mathrm{AB} 002632$ was the viral strand of the singlestranded fs- 2 phage genome. The first nucleotide of the recognition site of the restriction enzyme ScaI was taken as the zero coordinate of the sequence. The nucleotide sequence analysis of the $\mathrm{fs}-2 \mathrm{RF}$ revealed the presence of nine ORFs as indicated in Table 1 and Fig. 4(a). All the ORFs were preceded by potential ribosome-binding sites (Shine-Dalgarno sequence) (Table 1). The homology search showed that six of the nine predicted protein sequences were homologous to previously reported phage proteins (Table 2).

\section{DISCUSSION}

The general characteristics of $\mathrm{fs}-2$ are similar to those of other filamentous phages such as f1, fd, M13 (Model \& Russel, 1988), IKe (Peeters et al., 1985) and Pf3 (Luiten et al., 1985). fs-2 has a single-stranded DNA genome and is converted to a double-stranded RF in the host cell as seen in other filamentous phages.

The SDS-PAGE profile of the fs- 2 phage showed a single molecular species of about $4.5 \mathrm{kDa}$ which is predicted to be a major coat protein. Generally, coat structures of filamentous phages are composed of more than 2500 copies of a major coat protein between 4.5 and $5 \cdot 2 \mathrm{kDa}$ and a few copies of one or more minor proteins which are present in amounts too small to be detected by SDSPAGE (Tseng et al., 1990). The molecular mass of the major coat protein deduced from the nucleotide sequence (orf 73) was $7 \cdot 2 \mathrm{kDa}$ (Table 1), which is bigger than the estimated size of the major coat protein deduced from SDS-PAGE. This suggests that the major coat protein of fs- 2 may be synthesized via a precursor polypeptide with a signal sequence, as occurs in other filamentous phages (Model \& Russel, 1988). Indeed the $\mathrm{N}$-terminal sequence of 29 amino acid residues of the 
Table 1. Putative ORFs in the fs-2 phage sequence

\begin{tabular}{|c|c|c|c|c|c|}
\hline ORF $^{*}$ & $\begin{array}{l}\text { Position and } \\
\text { direction of } \\
\text { transcription }\end{array}$ & Start/stop & $\begin{array}{c}\text { No. of } \\
\text { bases }\end{array}$ & $\begin{array}{l}\text { Calculated } \\
\text { mol. mass of } \\
\text { product }(\mathrm{Da})\end{array}$ & $\begin{array}{l}\text { Shine-Dalgarno consensus } \\
\text { sequence (italic) and initiation } \\
\text { codon (upper case) }\end{array}$ \\
\hline orf 716 & $288>2436$ & ATG/TGA & 2148 & 81963 & actgttcaaggcggttac.ATG \\
\hline orf 104 & $2435>2747$ & ATG/TAA & 312 & 11623 & tgtaaggacaaacaaaaa.ATG \\
\hline orf 39 & $2760>2877$ & ATG/TGA & 117 & 4438 & ttaaataaggcggcataa.ATG \\
\hline orf 38 & $2876>2990$ & ATG/TAA & 114 & 4275 & aatagcaggtcaacaaag.ATG \\
\hline orf 73 & $3017>3236$ & ATG/TAA & 219 & 7246 & gtaatggagaattacacc.ATG \\
\hline orf 498 & $3317>4811$ & ATG/TAA & 1494 & 53935 & tttcgatggtttaaaaat.ATG \\
\hline orf 116 & $4820>5168$ & ATG/TAA & 348 & 12340 & tcacggagataatcaaaa.ATG \\
\hline orf 361 & $5193>6276$ & ATG/TAA & 1083 & 41192 & aaaaatgtcgttaacgtt.ATG \\
\hline orf 500 & $6259>7759$ & ATG/TGA & 1500 & 54018 & ttaaatcaggtgctcaaa.ATG \\
\hline
\end{tabular}

* The ORFs are designated by the number of codons they contain; for example orf 716 contains 716 codons.

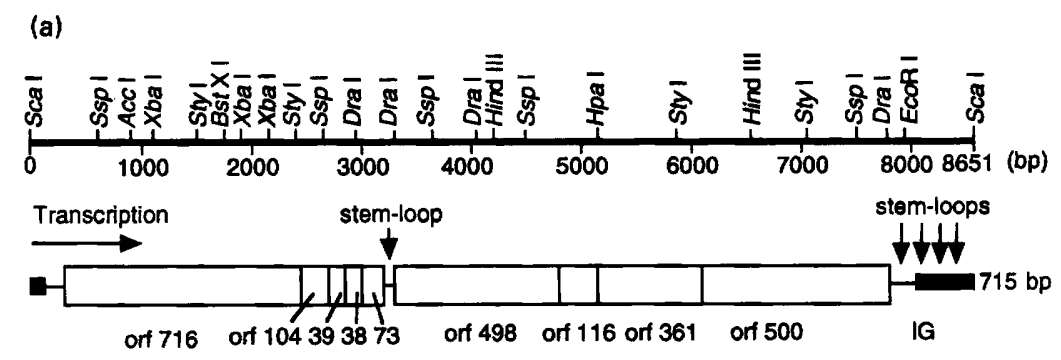

(b)

\section{fs-2 phage}

\begin{tabular}{|c|c|c|c|c|c|}
\hline of 3873 & orf 498 & off 116 & orf 361 & orf 500 & Genes \\
\hline \begin{tabular}{|l|l|}
38 & 73 \\
\end{tabular} & 498 & 1116 & 361 & 500 & ORF size \\
\hline
\end{tabular}

\section{M13 phage}

\begin{tabular}{|c|c|c|c|c|}
\hline IX VIII & III & VI & 1 & IV \\
\hline 3 3. 73 & 424 & 112 & 348 & 426 \\
\hline
\end{tabular}

Genes

ORF size

\section{fd phage}

\begin{tabular}{|c|c|c|c|c|}
\hline IX VIII & III & VI & 1 & IV \\
\hline \begin{tabular}{|l|l|}
33 & 74 \\
\end{tabular} & 425 & 113 & 349 & 427 \\
\hline
\end{tabular}

Genes

ORF size
Fig. 4. (a) Restriction map and deduced ORFs. The nine ORFs are indicated as open boxes. The location of intergenic regions (IG), stem-loop structures and $715 \mathrm{bp}$ sequences with similarity to RS2 of CTX $\Phi$ (black box) are indicated. (b) Comparison of fs-2 gene organization with coliphages $\mathrm{M} 13$ and $\mathrm{fd}$. Gene size is indicated schematically by the open boxes, with the number of codons inside each box. product of orf 73 shares several characteristics of signal sequences (Von Heijne, 1985). The deduced molecular mass of the mature major coat protein after cleavage of such a signal sequence would be approximately $4.5 \mathrm{kDa}$.

The fs-2 phage has a wide host range among $V$. cholerae $\mathrm{O} 139$ and $\mathrm{O} 1 \mathrm{El}$ Tor biotype strains. Some V. cholerae $\mathrm{O} 1$ classical biotype and non-O1, non-O139 strains are also sensitive. This suggests that the phage could be a vector of genes among a wide range of $V$. cholerae strains.

The RF of the fs- 2 phage is 8651 nucleotides long and its $\mathrm{G}+\mathrm{C}$ content is $44.51 \mathrm{~mol} \%$, which deviates from that of the host $V$. cholerae $(47-49 \mathrm{~mol} \%)$. The restriction enzyme map of fs-2 RF (Fig. 4a) is different from those of the other V. cholerae filamentous phages VSK (Kar $e t$ al., 1996) and CTXФ (Waldor \& Mekalanos, 1996).

orf 38 , orf 73 and orf 116 of the fs- 2 phage are homologous to the gene IX (minor coat protein; Stassen et al., 1992), gene VIII (major coat protein; Beck \& Zink, 1981) and gene VI (minor coat protein; Van Wenzenbeck et al., 1980) of coliphages, respectively. orf 361 and orf 500 are homologous to gene I and gene IV, respectively (Beck \& Zink, 1981), which are necessary for phage morphogenesis. The biggest ORF, orf 716 , is homologous to replication protein of phage HP1, which is necessary for replication of the phage DNA (Esposito et al., 1996). orf 498 is comparable in size and location to the gene III; however, there is no homology between them. The gene III may be so different because its 
Table 2. Similarity of the predicted ORF products to proteins in the databases

\begin{tabular}{|c|c|c|c|c|}
\hline ORF & Homologous protein ${ }^{*}$ & $\begin{array}{l}\text { Accession } \\
\text { no. }\end{array}$ & Identity/positives observed & $\begin{array}{l}\text { BLAST } \\
\text { score }\end{array}$ \\
\hline \multirow[t]{5}{*}{ orf 716} & \multirow{5}{*}{$\begin{array}{l}\text { Replication protein } \\
\text { (phage HP1) }\end{array}$} & \multirow[t]{7}{*}{ S69515 } & $47 \% / 61 \%$ in 103 residues & 246 \\
\hline & & & $34 \% / 61 \%$ in 98 residues & 147 \\
\hline & & & $56 \% / 75 \%$ in 32 residues & 105 \\
\hline & & & $22 \% / 43 \%$ in 44 residues & 49 \\
\hline & & & $26 \% / 52 \%$ in 23 residues & 38 \\
\hline orf 104 & \multirow{2}{*}{\multicolumn{2}{|c|}{$\begin{array}{l}\text { No homologue } \\
\text { No homologue }\end{array}$}} & & \\
\hline orf 39 & & & & \\
\hline orf 38 & $\begin{array}{l}\text { Gene IX protein } \\
\text { (phage I2-2) }\end{array}$ & S08089 & $44 \% / 56 \%$ in 25 residues & 46 \\
\hline orf 73 & $\begin{array}{l}\text { Gene VIII protein } \\
\text { (phage fd) }\end{array}$ & \multirow[t]{2}{*}{ A04226 } & \multirow[t]{2}{*}{$27 \% / 46 \%$ in 73 residues } & \multirow[t]{2}{*}{76} \\
\hline orf 498 & No homologue & & & \\
\hline orf 116 & $\begin{array}{l}\text { Gene VI protein } \\
\text { (phage M13) }\end{array}$ & B04275 & $20 \% / 40 \%$ in 94 residues & 75 \\
\hline \multirow[t]{4}{*}{ orf 361} & \multirow{4}{*}{$\begin{array}{l}\text { Gene I protein } \\
\text { (phage fd) }\end{array}$} & \multirow[t]{4}{*}{$\mathrm{A} 04262$} & $50 \% / 75 \%$ in 136 residues & 412 \\
\hline & & & $51 \% / 77 \%$ in 114 residues & 284 \\
\hline & & & $52 \% / 83 \%$ in 42 residues & 126 \\
\hline & & & $33 \% / 52 \%$ in 36 residues & 67 \\
\hline \multirow[t]{5}{*}{ orf 500} & \multirow{5}{*}{$\begin{array}{l}\text { Gene IV protein } \\
\text { (phage fd) }\end{array}$} & \multirow[t]{5}{*}{ A04268 } & $43 \% / 68 \%$ in 93 residues & 202 \\
\hline & & & $30 \% / 58 \%$ in 93 residues & 136 \\
\hline & & & $30 \% / 48 \%$ in 82 residues & 96 \\
\hline & & & $38 \% / 59 \%$ in 52 residues & 97 \\
\hline & & & $17 \% / 41 \%$ in 79 residues & 39 \\
\hline
\end{tabular}

* Only one homologous protein, with the highest homology, is listed for each ORF.

products participate in receptor binding and the receptor for different phages varies widely between bacterial species (Waldor \& Mekalanos, 1996). Between orf 716 and orf 38 there are two small ORFs, orf 104 and orf 39. Similarities in their size and location suggest that orf 104 corresponds to the gene $\mathrm{V}$ (ssDNA-binding protein) and orf 39 to the gene VII (minor coat protein) of coliphages, respectively; however, again no homology between these genes was found. A stem-loop structure which is also found in the other filamentous phages (Model \& Russel, 1988) is located between orf 73 and orf 498 (Fig. 4a). After orf 500 there is a large non-coding sequence containing stem-loop structures (Fig. 4a). This sequence is suspected to correspond to the intergenic region (IG) of coliphages which act as the origins of DNA replication, the packaging or morphogenetic signal and rho-independent terminator for transcription (Model \& Russel, 1988). Although the extent of homology between those genes is not particularly high and some genes show no homology, the overall genetic organization (size and location of genes, presence of intergenic region and stem-loop structures) of the filamentous phages appears to be preserved in the fs- 2 phage (Fig. 4b). For example, orf 73 , assigned as the gene encoding the major coat protein, is followed by the long orf 498, and then the short orf 116 is followed by two long ORFs, orf 361 and orf 500 . It would be interesting to determine the meaning of the similarities and differences of these genes in order to understand the evolutionary change of filamentous phages.

Southern hybridization analysis of $V$. cholerae chromosomal DNA using single-stranded fs- 2 phage DNA as a probe revealed that the phage was not integrated into the host chromosome, but a fragment that hybridized with the phage DNA was detected (data not shown). This result indicates that these host strains have sequences homologous to a part of the phage DNA in their chromosome which could allow integration by homologous recombination.

The homology search revealed that a 715 nucleotide fragment (nucleotides 8051-114) located in the large intergenic region of fs-2 was highly homologous $(97 \%$ identity) to a part of region RS2 (repetitive sequence 2) of the V. cholerae CTX $\Phi$ sequence (Waldor et al., 1997) which is also encoded by the virulence cassette (CTX core region) of the $V$. cholerae chromosome. The homologous part in the RS2 was designated as the rstB1 gene, which is speculated to be required for integration of the phage into the $V$. cholerae chromosome at a specific site. During the course of evolution the phage may have recombined with its host chromosome and the site may act as the hot-spot of recombination and integration. It is possible that the phage can mediate the 
transfer of some genetic elements (e.g. the virulence cassette) from pathogenic organisms to non-pathogenic ones. The study of filamentous phages may clarify the mechanism of gene transfer among organisms and the role of the phages in the evolution of natural populations.

\section{ACKNOWLEDGEMENTS}

We thank Masaaki Iwanaga for helpful discussions and for critical reading of the manuscript. We also thank Masahiko Ehara for providing the phage-producing V. cholerae O139 strain MDO14 and James B. Kaper and Hatsumi Taniguchi for worthwhile suggestions.

\section{REFERENCES}

Altschul, S. F., Gish, W., Miller, W., Myers, E. W. \& Lipman, D. J. (1990). Basic local alignment search tool. J Mol Biol 215, 403-410.

Beck, E. \& Zink, B. (1981). Nucleotide sequence and genome organization of filamentous bacteriophages $\mathrm{f} 1$ and $\mathrm{fd}$. Gene 16, $35-58$.

Birnboim, H. C. \& Doly, J. (1979). A rapid alkaline extraction procedure for recombinant plasmid DNA. Nucleic Acids Res 7, 1513-1523.

Ehara, M., Shimodori, S., Kojima, F., Ichinose, Y., Hirayama, T., Albert, M. J., Supawat, K., Honma, Y., Iwanaga, M. \& Amako, K. (1997). Characterization of filamentous phage of Vibrio cholerae O139 and O1. FEMS Microbiol Lett 154, 293-301.

Esposito, D., Fitzmaurice, W. P., Benjamin, R. C., Goodman, S. D., Waldman, A. S. \& Scocca, J. J. (1996). The complete nucleotide sequence of bacteriophage HP1 DNA. Nucleic Acids Res 12, 2360-2368.

Kar, S., Ghosh, R. K., Ghosh, A. N. \& Ghosh, A. (1996). Integration of the DNA of a novel filamentous bacteriophage VSK from Vibrio cholerae $\mathrm{O} 139$ into the host chromosomal DNA. FEMS Microbiol Lett 145, 17-22.

Laemmli, U. K. (1970). Cleavage of structural proteins during the assembly of the head of bacteriophage T4. Nature 227, 680-685.

Luiten, R. G. M., Putterman, D. G., Schoenmakers, J. G. G., Konings, R. N. H. \& Day, L. A. (1985). Nucleotide sequence of the genome of Pf3, an IncP-1 plasmid-specific filamentous bacteriophage of Pseudomonas aeruginosa. J Virol 56, 268-276.

McMaster, G. K. \& Carmichael, G. G. (1977). Analysis of single and double-stranded nucleic acids on polyacrylamide and agarose gels by using glyoxal and acridine orange. Proc Natl Acad Sci USA 74, $4835-4838$.

Model, P. \& Russel, M. (1988). Filamentous bacteriophage. In The Bacteriophages, pp. 375-456. Edited by R. Calender. New York: Plenum.
Peeters, B. P. H., Peters, R. M., Schoenmakers, J. G. G. \& Konings, R. N. H. (1985). Nucleotide sequence and genetic organization of the genome of the $\mathrm{N}$-specific filamentous bacteriophage IKe. Comparison with the genome of the F-specific filamentous phages M13, fd and f1. J Mol Biol 181, 27-39.

Rammanurthy, T., Garg, S., Sharma, R. \& 8 other authors (1993). Emergence of novel strain of Vibrio cholerae with epidemic potential in southern and eastern India. Lancet 341, 703-704.

Rowe, B. \& Frost, J. A. (1992). Vibrio phages and phage-typing. In Cholera, pp. 95-105. Edited by B. Dhihman \& B. G. William. New York: Plenum.

Sambrook, J., Fritsch, E. F. \& Maniatis, T. (1989). Molecular Cloning: a Laboratory Manual, 2nd edn. Cold Spring Harbor, NY: Cold Spring Harbor Laboratory.

Sanger, F., Nicklen, S. \& Coulson, A. R. (1977). DNA sequencing with chain-terminating inhibitors. Proc Natl Acad Sci USA 74, 5463-5467.

Shimodori, S., lida, K., Kojima, F., Takeda, A., Ehara, M. \& Amako, K. (1997). Morphological features of a filamentous phage of Vibrio cholerae O139 Bengal. Microbiol Immunol 41, 757-763.

Stassen, A. P., Schoenmakers, E. F., Yu, M., Schoenmakers, J. G. \& Konings, R. N. (1992). Nucleotide sequence of the genome of the filamentous bacteriophage 12-2: module evolution of the filamentous phage genome. $J \mathrm{Mol}$ Evol 34, 141-152.

Taniguchi, H., Sato, K., Ogawa, M., Udou, T. \& Mizuguchi, Y. (1984). Isolation and characterization of a flamentous phage, Vf33, specific for Vibrio parabaemolyticus. Microbiol Immunol 28, 327-337.

Towbin, H., Staehelin, T. \& Gordon, J. (1979). Electrophoretic transfer of proteins from polyacrylamide gels to nitrocellulose sheets : procedure and some applications. Proc Natl Acad Sci USA 76, 4350-4354.

Tseng, Y.-H., Lo, M.-C., Lin, K.-C., Pan, C.-C. \& Chang, R.-Y. (1990). Characterization of filamentous bacteriophage $\Phi$ Lf from Xanthomonas campestris pv. campestris. J Gen Virol 71, 1881-1884.

Van Wenzenbeek, P. M. G. F., Hulsebos, T. J. M. \& Schoenmakers, J. G. G. (1980). Nucleotide sequence of the filamentous bacteriophage M13 DNA genome: comparison with phage fd. Gene 11, 129-148.

Von Heijne, G. (1985). Signal sequences. The limits of variation. J Mol Biol 184, 99-105.

Waldor, M. K. \& Mekalanos, J. J. (1996). Lysogenic conversion by a filamentous phage encoding cholera toxin. Science 272, 1910-1914.

Waldor, M. K., Rubin, E. J., Pearson, G. D., Kimsey, H. \& Mekalanos, J. J. (1997). Regulation, replication, and integration function of the Vibrio cholerae CTX $\Phi$ are encoded by region RS2. Mol Microbiol 24, 917-926.

Received 15 September 1997; revised 25 February 1998; accepted 11 March 1998. 